УДК $\quad 339.923: 061.1 \mathrm{EPU}]: 336.7$

DOI https://doi.org/10.31212/tokovi.2019.3.ajl.151-169

Оригинални научни рад

Примљен: 1. 7. 2019.

Прихваћен: 3. 9. 2019.

Kornelija AJLEC

Department of History, Faculty of Arts, University of Ljubljana kornelija.ajlec@ff.uni-lj.si

\title{
European Payments Union and Negotiations on the Accession of Yugoslavia*
}

\begin{abstract}
Through the prism of original resources kept by the US National Archives, and secondary literature, the article deals with the American aspect of the negotiations for the accession of Yugoslavia to the European Payments Union (EPU), which operated between 1950 and 1958, with the primary objective of eliminating obstacles in the Western European trade. Yugoslavia never become a full member of the Union; it did, however, became affiliated with it just before the Union was abolished, when Yugoslavia achieved currency convertibility for foreign trade balances.
\end{abstract}

Key words: Yugoslavia, Organisation for Economic Co-operation and Development, OEEC, economic aid, European Payments Union

The Path to the Integration of the Commercial Payment System in Western Europe

In June of 1947, the United States of America adopted the European Recovery Program, better known as the Marshall Plan. The motives behind it were both humanitarian and strategic. The latter motive had

* The research was made possible by the support of the Fulbright scholarship and the national program Slovenian History (P6-0235) funded by the Slovenian Research Agency (ARRS). I would like to thank Dr. Aleksandar Životić, Dr. Božo Repe, Dr. Dušan Nečak, Dr. Peter Mikša, Maja Vehar, Dr. Claire Strom, and Ivanka Ponikvar, MA, for their insight and support. 
a particularly direct impact on European integration, part of which was the establishment of a new economic order in Europe. ${ }^{1}$ Such watershed moments are the fruit of a decade of long negotiations or epochal turning points that call for a break with all the causes that led to them. After one such critical turning point, namely World War II, agriculture, industry and services were severely damaged. Western Europe was particularly successful in tackling the effects of the war. Belgium, Norway, Sweden and the United Kingdom managed to achieve pre-war production levels by the end of 1946 due to their intensive post-war recovery, while France reached $98 \%$ and the Netherlands $83 \%$ of their pre-war production. Slower growth was present only in Italy, Greece and West Germany, where major war damage and the post-war political and strategic situation of the Cold War hindered reconstruction. ${ }^{2}$

Western Europe faced a balance of payments crisis as early as 1947, despite the rapid signs of recovery. ${ }^{3}$ The crisis was caused by a high demand for imports of raw materials, food and other products from abroad. During the post-war reconstruction period, the countries of Western Europe opted for an expansive monetary policy to ensure their population's high or full employment. With social security in place, the standard of living increased, and consequently also consumer demand for various goods. ${ }^{4}$ After World War II, international trade in Europe was conducted on the basis of bilateral agreements, which determined the value of annual trade between two countries and a convertible exchange rate between individual currencies. All of that had to be worked out in order to stabilize the balances of payments. According to the basic principle, equilibrium is achieved

1 Michael J. Hogan, The Marshall Plan. America, Britain and the Reconstruction of Western Europe, 1947-1952, (Cambridge: Cambridge University Press, 1987), 165.

2 Byron Gerald August, The Economics of International Payments Unions and Clearing Houses. Theory and Measurement, (London: Macmillan Press, 1997), 152.

3 Balance of payments is a systematic record of all economic transactions of one country's entities with entities of other countries over a given period of time. Balance of payments covers flows of goods, services and capital with a foreign market over a given period of time. There are two types of economic transactions: credit transactions and debit transactions. Credit transactions take into account the export of goods or services, unilateral transfers of capital to the country, capital inflows based on loans, direct and portfolio investment, and the utilization of foreign exchange reserves. Debit transactions include imports of goods and services, unilateral transfers to foreign entities, and outflows of capital on the basis of loans granted to foreign entities, direct and portfolio investments abroad, and the deposit of foreign currency reserves abroad. The balance of payments can be divided into three sub-balances: current accounts, capital-financial accounts, and balance sheets of net errors and omissions. More in: International Monetary Fund, Balance of Payments Manual, (1993), 6.

4 August, The Economics of International Payments, 152-153. 
when revenues arising from exports cover expenditures arising from imports. Each country therefore aims to achieve at least a state of equilibrium between income and expenditure, or record surpluses in the balance sheet. If countries were unable to replace imports with an equal amount of exports, they had to cover the resulting debt with monetary payments. The problem arose when the debt increased so much that creditor states did not want to accept large amounts of foreign currencies, as it would surpass their need to buy new goods from them. In addition, general convertibility systems were not in place to allow for that money to be spent on trading with a third country. ${ }^{5}$ Under such conditions, European trade was extremely limited; European products were not sufficiently utilized, and above all, economic development was hindered. ${ }^{6}$

Consequently, the crisis period of war and post-war reconstruction eroded the ability of Western Europe to stabilize its balance of payments. They tried to tackle the issue by extending repayment of bilateral capital-financial accounts, which led to a continuous bilateral imbalance. Furthermore, such circumstances could lead to a re-emergence of discriminatory trade practices, which were a constant in the 1920s and 1930s, when ideologically and politically related countries concluded more favorable agreements. The United States and most Western European countries considered such practices dangerous and therefore undesirable. The market crisis motivated the creators of the subsequent Marshall Plan to subject Europe to a reform package similar to the one carried out during the Great Depression in the United States; a sort of European New Deal. ${ }^{7}$ Hence, the increasingly inevitable paralysis of European trade was the major motivation for the creation of the Organization for European Economic Cooperation (OEEC), ${ }^{8}$ which initially brought a group of 16 Euro-

$5 \quad$ Example: Belgium was traditionally a steel exporter, while Denmark and Norway imported it. Conversely, Denmark and Norway exported less expensive products, such as dairy products and fish. These could not be exported to Belgium in sufficient quantity to cover the purchase of the required quantity of steel; furthermore, they could not cover their imports with surpluses in the balance sheet with a third country. Thus, Denmark and Norway had to reduce the amount of purchased steel in order not to accumulate too much debt.

6 National Archives and Records Administration (NARA), Record Group files 469 (RG 469), Records of US Foreign assistance agencies, 1948-1961 (RUSFA), Entry 1457, Box 3, EPU-1951, The European Payments Union, 1.

7 Hogan, The Marshall Plan, 293.

8 Its name was changed into the Organization for Economic Co-operation and Development (OECD) in 1961. 
pean countries ${ }^{9}$ into the US sphere of influence. Although the most visible role of the OEEC was the division of US economic aid as part of the Marshall Plan, its paramount task was to remove obstacles in European trade. Therefore, a special mechanism was set up within the OEEC, which became the first step toward the integration of European post-war trade - the European Payments Union (EPU). ${ }^{10}$

The initial negotiations for the establishment of the EPU, and therefore the liberalization of trade, began in 1948. After two years, in July of $1950,{ }^{11}$ and after three failed agreements, the negotiators agreed on the three main pillars of the OEEC: 1) the European Payments Union, 2) the abolition of quantitative import restrictions, and 3) an informal consultation mechanism on important economic policy issues of each member state. ${ }^{12}$

\section{The European Payments Union}

The EPU introduced financial mechanisms that paved the way for European trade integration. The goals of the Union were to create a single competitive market in Western Europe and achieve general currency convertibility. Countries did not deal with the equilibrium of the balance of payments with individual trading partners, but with the Union as a whole. The system promoted trans-European trade by allowing each member to compensate their deficit in trading with one member with the surplus they had in trading with another member of the Union. ${ }^{13}$

The implementation of the EPU measures was taken over by the Bank of International Settlements (BIS), the policy was supervised by the EPU's governing board, while the initial capital investment of $\$ 350$ mil-

9 Austria, Belgium, Denmark, France, Greece, Iceland, Ireland, Italy, Luxembourg, the Netherlands, Norway, Portugal, Sweden, Switzerland, Turkey, the United Kingdom, and the Federal Republic of Germany. The latter was initially represented by the joint leadership of the American and British occupying zones (The Bizone) and the French occupation zone, prior to its declaration of statehood. In addition, the Free Territory of Trieste operated in the OEEC, until it was re-integrated into Italy. More at the Organization for European Economic Co-operation, date of access: June 2019, https://www.oecd.org/general/organisationforeuropeaneconomicco-operation.htm

10 August, The Economics of International Payments, 154-155.

11 NARA, RG 459, Entry 1457, Box 3, EPU-1951, Memorandum on European Payments Union, 25 July 1950, 1.

12 August, The Economics of International Payments, 155; Hogan, The Marshall Plan, 165.

13 NARA, RG 459, Entry 1457, Box 3, EPU-1951, The European Payments Union, 1; Ljubiša S. Adamović, Politička i društvenoekonomska kretanja u savremenom svetu, (Beograd, 1963), 34. 
lion came from the Marshall Plan. The founders of the agreement highlighted the following Union objectives: ${ }^{14}$

1. Ensuring the liberalization of European internal trade;

2. Supporting members of the OEEC on their path to independence from "extraordinary outside assistance";

3. Ensuring a high and stable level of trade and employment;

4. Restoring general currency convertibility.

The multilateral payment mechanism introduced by the EPU had four basic components: ${ }^{15}$

1. the central banks of OEEC members provided unrestricted loans for trade within the OEEC area at constant exchange rates;

2. bilateral balances were made monthly for each of the member states;

3. the net balance of payments of individual OEEC members was calculated in relation to the state of the Union as a whole;

4. net deficit countries partly repaid their monthly deficits in gold and dollars, while the Union extended a loan for the remainder of their debt (only $25 \%$ of the debt on average). ${ }^{16}$

These provisions ensured that countries could not resort to discriminatory trade policies. Each member state was given a symmetrical credit and debit quota, which was initially valued at $15 \%$ of the value of transactions in the dollar value of 1949, both imports and exports. Within this percentage, a country could collect credit or debit transactions. The closer they got to the maximum quantity of the quota, the higher were their monthly payments in gold and dollar reserves. The maximum payment delay was $60 \%$ of the quota. In this way, the EPU provided permanent trade

14 August, The Economics of International Payments, 156; NARA, RG 459, Entry 1457, Box 3, EPU-1951, The European Payments Union, 3.

15 August, The Economics of International Payments, 156.

16 These percentages gradually increased until 1958, but never exceeded $60 \%$ of the debt. 
credits for the revitalization of trade within the OEEC. ${ }^{17}$ If countries came close to the maximum, the Union could react with three mechanisms: ${ }^{18}$

1. adapting liberalized policies, such as the reintroduction of quantitative limits for debtors, and greater liberalization for lenders;

2. changes in macroeconomic policies that would alter import consumption and divert it to exports;

3. approval of additional loans above quotas.

With such mechanisms, the EPU secured liquidity in the international trade of OEEC members, which reached a value of nearly $\$ 140$ billion between July 1950 and December 1958 (when the EPU was abolished). It is important to note that most of the trade was still bilateral, but because of the Union, it was faster and more transparent. Payment discipline increased, resulting in substantial bilateral surpluses of $\$ 23.2$ billion. As much as $80 \%$ of all debts were paid in gold, and only $20 \%$ in loans. The success of the EPU was therefore primarily evident through the establishment of effective multilateral clearing mechanisms. ${ }^{19}$

\section{Currency convertibility}

One of the main goals of the EPU was the reinstatement of convertibility of members' currencies. If a currency is convertible, the economic protagonists may exchange the currency for gold or other currencies, paying off their deficits and loans with greater ease. Non-residential convertibility is crucial in international trade, since it enables foreign exporters to use their profit to purchase goods from anyone and in any currency for purchase or payment in any other currency. Residential convertibility affects those individuals who wish to exchange the currency in their country for any other currency. Pressured by the United States, Great Britain was the first to introduce convertibility in 1947. One pound was worth four dollars, while convertibility was backed by a US loan of $\$ 2.5$ billion, which evaporated in five weeks. Great Britain was thus forced to eliminate convertibility. Other countries and the OEEC dealt with the question of convertibility with caution. It was June of 1953 when the members of

17 August, The Economics of International Payments, 157.

18 Ibid., 158.

19 Ibid. 
the OEEC started offering transactions in European currencies outside the EPU mechanism to individuals. In 1954, the London Commodity Exchange restarted their operations and offered sales in European currencies for goods purchased in dollars. Henceforth, Great Britain and West Germany took the main role in such trades, and increased the transfer areas in pounds and deutschemarks, becoming intermediaries of sorts between other European currencies and the dollar. ${ }^{20}$ By 1958, all the member states, with the exception of Greece, Iceland, and Turkey, simultaneously reintroduced convertibility for their currencies for all kinds of transactions. By reinstating the convertibility system, the importance of the EPU quickly diminished. Hence, it ceased functioning on January 1, 1959. ${ }^{21}$

\section{Yugoslavia's Advancement Toward the European Payments Union}

After the Tito-Stalin split in March of 1948, Yugoslavia slowly turned toward the West due to the economic and political blockade imposed by the Soviet Union and its Eastern-European allies. Yugoslavia primarily relied on the United States and partly on Great Britain and France, who supplied large amounts of economic aid after 1951. It was an alternative to the Marshall Plan; a part of which Yugoslavia could not become in 1947 due to Moscow's dictates. It was also repeatedly rejected by the United States after the dispute. ${ }^{22}$ Nevertheless, the United States was Yugoslavia's biggest economic partner after 1950, since two thirds of the Yugoslavia's international trade was with the States. The reasons are twofold: the United States hoped that Yugoslavia would have to adopt at least some principles of free trade through the increased flow of Western economic aid, and trade with the West; which, according to Washington's predictions, would be followed by a political transformation and democratization. ${ }^{23}$ On the other hand, Yugoslavia was forced to accept foreign aid, since until Stalin's death all doors to the East had been closed. ${ }^{24}$

\section{Ibid., 163-164.}

21 Ibid., 165.

22 John R. Lampe et al., Yugoslav-American Economic Relations Since World War II, (Durham and London: Duke University Press, 1990), 28.

23 E.g.: Lorraine M. Lees, Keeping Tito Afloat. The United States, Yugoslavia and the Cold War, (The Pennsylvania State University, 1997).

24 Andrej Marković, Ivan Obadić, „A Socialist Developing Country in a Western Capitalist Club. Yugoslavia and the OEEC/OECD, 1955-1980", The OECD and the International Political Economy Since 1948, eds Matthieu Leimgruber, Matthias Schmelzer, (London: Palgrave Macmillan, 2017), 90. 
It soon became evident that one of the most troubling factors of the Yugoslav economy was the instability of the foreign markets. The main reason for its trade balance deficit was its strategy of accelerated economic growth, which was based on industrialization, which depended on imports, ${ }^{25}$ while the country did not export enough. Nevertheless, in 1951, the Yugoslav Government asked the United States to release the foreign currencies past international mechanisms in order to overcome the "crisis of the Yugoslav economy"26 by purchasing raw materials. The US representatives warned the Yugoslav Government that the crisis would not be manageable by regular troubleshooting such as within the Yugoslav proposal, but only with a long-term strategy. Foreign Minister Edvard Kardelj then said that the Yugoslav Government was also hoping for a definitive solution in the form of an agreement on Yugoslavia's partnership in the newly founded EPU, or even in the OEEC. He did expect that membership was not an option before 1953 or $1954 .{ }^{27}$ Like other countries outside the EPU, Yugoslavia transacted with its trade partners through bilateral trade and payments agreements that determined the value of import, export and quantitative trade provisions. When Kardelj expressed interest in joining the EPU, the American Government warned Yugoslavia that it would first have to fulfill certain technical requirements. ${ }^{28}$ The said phrase is not explained further in the document. However, other documents point out that it is an adjustment of the Economic Cooperation Act, which also dealt with OEEC and EPU membership and their founding documents. ${ }^{29}$

But Yugoslavia was not discouraged by the technical requirements. The United States, however, remained cautious, as shown in the letters by the US economic attaché in Belgrade, Emile Despres, ${ }^{30}$ who wrote to

25 Oskar Kovač, Spoljnoekonomska ravnoteža i privredni rast. Problemi i iskustva Jugoslavije, (Beograd: Institut ekonomskih nauka, 1973).

26 In March 1951, the minister of foreign affairs, Edvard Kardelj, asked the ambassador for an immediate release of $£ 4$ million and \$20 million; as a donation or as a loan. More in: Foreign Relations of the United States (FRUS), 1951, Europe: Political and Economic Developments, Vol. IV, Part 2, document 406, date of access June 2019, https://history.state.gov/historicaldocuments/frus1951v04p2/d406

27 Ibid.

28 NARA, RG 459, Entry 1457, Box 3, EPU-1951, Informal memorandum on dealing with currency transferability, 31 July 1950, 3-4.

29 NARA, RG 459, Entry 1457, Box 3, EPU-1951, Memorandum on E.P.U., 5 February 1951.

30 Despres was an experienced economist, specialized in international monetary policy. He was one of the first people to warn about the exchange control system introduced by the treasurer of the Third Reich, Hjalmar Schacht, which ultimately led to the rearmament of Germany, without risking a balance sheet crisis. Despres was also 
Stanislav Kopčok, deputy foreign trade minister, urging him to consider alternative ways of resolving the problem of currency convertibility and paying off the debts. One of the propositions was to conclude a series of agreements on payment transfers with Yugoslavia's largest European trading partners. All the agreements would be identical, even though formally they would be bilateral agreements, which would ensure Yugoslavia the following:

1. the Yugoslav Government would be able to convert the surplus of one foreign currency into a currency of any other country with which Yugoslavia would sign a similar agreement; and

2. the Yugoslav Government could use the surplus of one foreign currency to cover the deficit with any other trading partner with which Yugoslavia would sign a similar agreement.

Despres's idea suggested a parallel EPU system that would - if implemented - act as a similar substitute as the tripartite economic aid acted in lieu of the Marshall Plan. Yugoslavia would not be a member of the EPU, but it would have access to its most important mechanisms outside the Union. Despres believed that such an arrangement would only be temporary and would help Yugoslavia overcome the period before it finally joined the EPU. ${ }^{31}$ The proposition was, however, not entirely coordinated on the US side. Ralph C. Wood, director of the Finance and Trade Division at the Office of the US Special Representative in Europe, based in Paris, wrote in a letter to Despres that it was necessary to conduct certain talks before any further procedure leading to the conclusion of payment transfers agreements. He particularly found it necessary to consider whether Yugoslavia was actually capable of creating a surplus in one part of its trade, which could cover its deficit in the other part. ${ }^{32}$ Despres immediately dismissed this claim by stating that the current trade exchange was impeded by all the obstacles that arose from the lack of precisely such

an adviser to the US State Department on German finances, and a member of the US delegation at the Potsdam Conference. Prior to his departure for Yugoslavia, he worked at the Economic Cooperation Administration, which managed the Marshall Plan. The ECA opened its office at the US Embassy in Belgrade in 1951, when Emile Despres arrived, with the objective of delivering aid.

31 NARA, RG 459, Entry 1457, Box 3, EPU-1951, Informal memorandum on dealing with currency transferability, 31 July 1950, 3-4.

32 NARA, RG 459, Entry 1457, Box 3, EPU-1951, A Ralph C. Woods letter to Emile Despres, 20 August 1951. 
agreements. ${ }^{33}$ Nevertheless, Woods, despite his own reluctance, reported that in the months since Kardelj's intention, the US advocated through their representatives in the EPU that Yugoslavia's accession to the organization would facilitate the supply of economic and military aid. The United States represented that position mainly due to strategic motivations. It was, however, restrained while communicating with Yugoslavia. The official appeal advised the US representatives in Belgrade not to give the impression that Yugoslavia's membership in the EPU was only a matter of time. ${ }^{34}$

Meanwhile, EPU membership became one of Yugoslavia's main foreign trade policy goals. Josip Broz Tito himself expressed the intention of joining the EPU to a group of US journalists from the Christian Science Monitor in August of 1951 during a press conference at Brioni. He made it clear that Yugoslavia wished to become a member of the Union immediately, although its membership ultimately depended on other countries. ${ }^{35}$ Trade Minister Milentije Popović added that they were not aware what the position of other EPU members was regarding the potential accession of Yugoslavia. ${ }^{36}$ The US diplomats suspected that the unusual display of intentions was orchestrated by the Yugoslav leadership to provoke a response that would help them evaluate the level of support they had..$^{37}$ The 17 August news conference was followed by a three-hour discussion between Despres and Kopčok. They debated the Yugoslav membership in the EPU and Despres's proposition on transaction agreements. Kopčok explained that bilateral agreements were quite expensive for Yugoslavia and added that negotiating with every country was exhausting and even demeaning. He made it clear that Yugoslavia would not beg to be accepted into the EPU, but also said that technical requirements could not be the only thing barring Yugoslavia from joining. Despres confirmed that technical requirements were just one of the impediments. The issue of the debit and deficit status of Yugoslavia compared to the EPU members and the problem of the difference between the economic institutions of Yugoslavia and those of the EPU members, which could impede the liberalization of the Yugoslav trade, still remained open.

33 NARA, RG 459, Entry 1457, Box 3, EPU-1951, Emile Despres letter to Ralph C. Woods, 23 August 1951.

34 NARA, RG 459, Entry 1457, Box 3, EPU-1951, A Ralph C. Woods letter to Emile Despres, 20 August 1951.

35 NARA, RG 459, Entry 1457, Box 3, EPU-1951, Emile Despres letter to Ralph C. Woods, 23. August 1951.

36 NARA, RG 459, Entry 1457, Box 3, EPU-1951, George V. Allen telegram, 10 August 1951.

37 Ibid. 
Much of the concern was related to the EPU governing board, which coordinated the fiscal and payment policies between the EPU members. ${ }^{38}$ The board could easily decide not to accept Yugoslavia due to its debt, or could first demand the repayment of debts to the members of the Union. Yugoslavia was not capable of doing that on its own, which meant the United States would have to subsidize it. However, the United States was not willing to do that ${ }^{39}$ Despres then reintroduced the idea of Yugoslavia concluding a series of payment transfer agreements. He could not guarantee a successful implementation, but he did relay a message from the US representative in the EPU, who said that such a solution was possible with intensive negotiations. Kopčok expressed fears that concluding such agreements would make the EPU members demand the decrease of swing trading from Yugoslavia, ${ }^{40}$ which they could not afford in their current state.

In early September, the American Embassy informed Kopčok after a series of correspondence with the US representatives in Paris and Belgrade, that Yugoslavia would be rejected if it applied for membership in the EPU at that time. Kopčok thus asked to try to establish the proposed payment transfer agreements between the member states of the Union and Yugoslavia. ${ }^{41}$ The Embassy lobbied strongly for the agreements to be implemented, but not only for practical reasons that would facilitate business in international trade. They pointed out that Yugoslavia was ready to abandon the policy of nonparticipation in international organizations where the countries of the Western Bloc were exclusive members. It was therefore necessary to take advantage of Yugoslavia's desire to join a West-dominated organization. ${ }^{42}$ Despite Belgrade's bidding, Paris was still reserved about the pay-

38 NARA, RG 459, Entry 1457, Box 3, EPU-1951, Robert F. Allen telegram, 21 August 1951.

39 NARA, RG 459, Entry 1457, Box 3, EPU-1952, Telegram from Paris to London and Belgrade, 16 February 1952.

40 NARA, RG 459, Entry 1457, Box 3, EPU-1951, Robert F. Allen telegram, 21 August 1951.

41 NARA, RG 459, Entry 1457, Box 3, EPU-1951, Richard F. Allen telegram to Paris, 7. September 1951.

42 Ibid. - This attitude was reflected also in the conclusion of the so-called Balkan Pact of 1953/54, when Yugoslavia entered into a political and military alliance with Greece and Turkey. This alliance indirectly tied Yugoslavia to NATO. In 1952 Yugoslavia also managed to advance its role in the United Nations by being elected into the UN's Economic and Social Council. In parallel rapprochement of Yugoslavia toward the West and specifically the EPU, Yugoslavia entered negotiations for membership within the Council of Europe, but for the most part, they were not successful and largely ended in 1953. Later, Yugoslavia was not interested in joining other integration processes in Europe, especially after the death of Stalin resulting in reserved relations with the European Economic Community as it was formed in 1958. More in: Ратомир 
ment transfer agreement. They believed Yugoslavia did not create enough surplus as a major debtor to utilize such agreements efficiently. On the other hand, they still thought the agreements would facilitate the use of tripartite aid, especially the aid donated by France. ${ }^{43}$ After intensive correspondence and talks with Despres in Paris, the US State Department finally approved the start of negotiations to conclude transfer agreements at the end of September of 1951. At that time, they decided that Yugoslavia should be supported in joining the organization, if it still wished to. The increased cooperation between Yugoslavia and Western Europe was in line with the goals regarding Yugoslavia set by US policy. Furthermore, the Americans noticed that Yugoslavia was shifting its exports from potential buyers in Europe to the United States in order to acquire dollars to buy goods in Europe, when quotas within bilateral agreements would eventually run out. The State Department believed that such non-economical practice would cease with the conclusion of the transfer agreements. ${ }^{44}$

The accession was supposed to be gradual. US financial experts simply did not understand the Yugoslav economic system well enough to vouch for all their debts to the EPU members. The Yugoslav membership in the EPU was therefore considered too risky, both to the members of the Union and to the United States, until it was absolutely clear what its system of self-management and its foreign trade policy meant. ${ }^{45}$ They were, however, aware that the members of the EPU could reject the proposition for concluding payment transfer agreements. They utilized the interim period of studying the Yugoslav economy to start promoting the idea among the members of the Union. The US representatives in Europe were instructed to present the idea on agreements to Great Britain and France first, at the meeting in Paris, where they could come to a consensus for a coordinated conclusion of agreements, while the evolution into full membership was not completely ruled out. ${ }^{46}$

Миликић, Заборављена европска епизода: Југославија и Савет Европе 1949-1958, (Београд: Институт за савремену историју, 2014); Никола Мијатов, „Југославија и уједињавање Западне Европе 1950-1958“, Токови историје 2/2016, 177-196; Yugoslavia: Political Diaries, 1918-1965, Vol. 4, ed. Robert L. Jarman, (London: The Broadway, 1997);

43 NARA, RG 459, Entry 1457, Box 3, EPU-1951, Richard F. Allen telegram to Paris, 12 September 1951.

44 NARA, RG 459, Entry 1457, Box 3, EPU-1951, State Department telegram to Embassy in Belgrade, 28 September 1951.

45 NARA, RG 459, Entry 1457, Box 7, OEEC-1952, Jan. thru May, Telegram from Economic Cooperation Administration to OSR Paris, 21 January 1952, 1.

46 Ibid. 
Even though the State Department gave the green light for negotiations on the agreements, things did not move an inch for a couple of months, despite Yugoslavia's constant bidding. ${ }^{47}$ The first talks between the US representative and the representatives of Great Britain and France in the governing board of the EPU took place no earlier than late February of 1952. The initial reactions of Hugh Ellis-Reese, the British representative, were mostly reserved, but not directly unfavorable; while the French representative, Pierre Calvet, believed the French Government would probably support the proposition, as France at that time had a trade surplus with Yugoslavia. ${ }^{48}$ Due to the British reservations, new talks followed, where the British reiterated the doubts of some US diplomats that the agreements would prove to be fruitless because of Yugoslavia's debt to the members of the Union. Furthermore, Great Britain had payment issues of its own, so they did not want to deal with countries outside the Union. ${ }^{49}$

Table 1: Demonstration of the trade conditions of Yugoslavia as related to the EPU countries for the year 1951 (in millions) ${ }^{50}$

\begin{tabular}{|l|r|r|r|c|}
\hline & YU exports to & YU imports from & \multicolumn{1}{c|}{+ or -} & Currency \\
\hline Austria & 335.371 & 289.010 & +56.361 & Schilling \\
\hline Benelux & 228.207 & 607.793 & -399.586 & Belgian franc \\
\hline Denmark & 7.810 & 20.076 & -12.266 & Danish krone \\
\hline France & 2.675 & 4.512 & -1.837 & French franc \\
\hline Italy & 8.517 & 15.635 & -7.118 & Italian lira \\
\hline The Netherlands & 13.422 & 35.684 & -22.262 & Dutch guilder \\
\hline Sweden & 11.323 & 15.070 & -3.747 & Swedish krone \\
\hline Switzerland & 32.875 & 16.964 & -15.783 & Swiss franc \\
\hline Great Britain & 10.694 & 10.943 & -249 & British pound \\
\hline West Germany & 160.638 & 183.729 & -23.091 & Deutsche mark \\
\hline
\end{tabular}

47 NARA, RG 459, Entry 1457, Box 3, EPU-1952, Robert F. Allen Telegram to Paris, 16 February 1952.

48 NARA, RG 459, Entry 1457, Box 3, EPU-1952, Telegram from Paris to Embassy in Belgrade, 27 February 1952.

49 NARA, RG 459, Entry 1457, Box 3, EPU-1952, James Williams Riddleberger Telegram from Paris to Belgrade, 8 March 1952.

50 NARA, RG 459, Entry 1457, Box 3, EPU-1952, E. A. J. Johnson Memorandum, 9 May 1952. 
In 1951, Yugoslavia actually had a large debt to the EPU members. The only surplus it had was with Austria, while the balance with Great Britain was nearly even. ${ }^{51}$ This led to a complete cessation of all further talks on Yugoslavia's accession into the Union, which itself was busy evaluating its own operations in 1952. As a result, a series of meetings took place by the end of summer, but Yugoslavia was not the focal issue. It was in autumn, during the second regional conference of mission leaders of the Mutual Security Agency (MSA), which oversaw the military and economic aid to the European countries, when they agreed upon giving $\mathrm{Yu}-$ goslavia a special amount between 20 and 25 million dollars as part of the aid to Yugoslavia for 1953. The purpose of that donation was for Yugoslavia to repay its debts to the countries of the EPU according to the general EPU settlement rules. That way, Yugoslavia could establish a temporary and loose regime of trade with the EPU - similar to the potential conclusion of the transaction agreements - where the main trade partner would be the BIS. That would enable allow for an easier implementation of such propositions, as opposed to complying with all the EPU governing board requirements. ${ }^{52}$ But even such an arrangement would require the Board's authorization.

The Board was supposed to debate the inclusion of Yugoslavia to the convertibility system at the $30^{\text {th }}$ Board session, in November of 1952 . They decided to deliberate on the issue during the next session in December, where they were to discuss similar intentions of Spain, Egypt and Japan. ${ }^{53}$ But since the next session was summoned in haste and only the members who had their headquarters in Paris were present, the discussion was rescheduled for the next meeting. ${ }^{54}$ The partnership with Yugoslavia was finally discussed at the $32^{\text {nd }}$ Board session, where they did not discuss payment transfer agreements, but Yugoslavia's potential accession to the currency convertibility system. While certain members advocated implementing this cooperation, other members, notably Switzerland, refused to support the "experiment" for "political reasons." The governing board therefore decided not to allow the partial integration of Yugoslavia and the other aforementioned countries into the EPU system.

\footnotetext{
51 Ibid.

52 NARA, RG 459, Entry 1457, Box 3, EPU-1952, State Department letter to Paris and Belgrade, 28 November 1952.

53 NARA, RG 459, Entry 1457, Box 3, EPU-1952, Report on 30th Session of the EPU Managing Board, Nov. 17-22, 11 December 1952, 1.

54 NARA, RG 459, Entry 1457, Box 3, EPU-1952, Report on 31th Session of the EPU Managing Board, Dec. 2-3, 11 December 1952.
} 
They did, however, agree unanimously to repeat the entire process within six months to one year. ${ }^{55}$

The US Administration faced a dilemma. The American Embassy in Belgrade still signaled the need to bring Yugoslavia closer to the EPU, while the Yugoslav Government still lobbied for membership or as strong an affiliation as possible. Washington continued to receive ambiguous reports from US representatives in Paris on the advisability of accepting Yugoslavia, considering its economic and foreign policy situation, which was in part still tense, mostly due to the issue of Trieste. Washington was ready to pick any side. If the main objective of Yugoslavia's cooperation was to bring it closer to Western Europe and the Western Bloc, the United States was ready to support the consolidation of Yugoslavia's foreign trade balance with US purposive subsidies - which was also allowed by the Rules of Commercial Policy, which governed the EPU. If, however, the primary objective of bringing Yugoslavia closer to the EPU was to alleviate their debt issues by offering them simpler trading with creditors, then Washington believed the entire effort was not justifiable. ${ }^{56}$

Numerous concerns arose during the implementation of any of the objectives. They worried how the American public would accept the fact that their government would let other countries help Yugoslavia with no restraints in the event Yugoslavia was allowed to join the EPU. If they continued to limit the aid via the MSA supervision over Yugoslavia's transactions, what would be the response of the Yugoslav Government and the other members of the EPU? ${ }^{57}$ On the one hand, Washington hoped their fear was an overreaction, since Yugoslavia would have to accept US supervision of their transactions due to their debt. If that would not work, they would try the method of soft persuasion. They would attempt to convince the Yugoslav Government that the members of the Union did not know the Yugoslav system well enough, so they would suggest an implementation of additional safeguards provided by the United States. Should this suggestion fail, they would resort to extortion. The US was willing to withhold its economic aid of \$25 million in 1954 if Yugoslavia refused to accept US supervision as a condition of operating within the EPU. ${ }^{58}$ There was, however, still the issue of technical requirements, which, according to Kopčok, could

55 NARA, RG 459, Entry 1457, Box 3, EPU-1952, Report on 32nd Session of the EPU Managing Board, Dec. 15-18, 22 December 1952.

56 NARA, RG 459, Entry 1457, Box 3, EPU-1953, Lester J. Gottlieb Memorandum to Edgar A. J. Johnson on Yugo Participation in EPU, 16 January 1953, 1.

57 Ibid.

58 Ibid., 2. 
be resolved. Yugoslavia's ability of adjusting its system according to the EPU founding documents was still questionable; especially the trade policy rules that tackled discriminatory policies, dealt with the liberalization of trade, etc. Washington was thus initially ready to negotiate a temporary membership for Yugoslavia for a period of one year, to see how Yugoslavia would adapt to the rules and what kinds of relationships the other members of the Union would create. ${ }^{59}$

Just a few days after the expressed doubts from Washington, the EPU governing board agreed at the $33^{\text {rd }}$ session in January 1953 to start the negotiations to let Yugoslavia repay its trade debts to the members of the Union through the EPU mechanism by exchanging the income currency to the debt currency via the convertibility mechanisms.$^{60}$ It was in fact an implementation of the proposition given by Emile Despres in July 1950. The members of the Board still had misgivings about the benefits of bringing Yugoslavia closer, since Yugoslavia primarily had remained an indebted country. They estimated, however, that some useful compensation could come via trade with Turkey, Greece, and Austria. ${ }^{61}$

Quite soon, it became evident that the initial agreement on cooperating with Yugoslavia was not final. In March of 1953, a proposition for Yugoslavia to start cooperating with the EPU by June was issued but not supported. The only agreement was that the representatives of the individual member countries would discuss the issue with their governments. ${ }^{62}$ However, by the next session, the governing board finally confirmed that Yugoslavia would start preparations to compensate the currencies to repay its debt within the EPU convertibility systems. At the same time, an identical mechanism was authorized for Spain, Egypt and Japan. ${ }^{63}$

\section{In Lieu of EPU Membership, Observer Status in the OEEC}

Despite giving Yugoslavia access to the EPU convertibility mechanisms, the status of Yugoslav payments did not improve much. Great Britain revoked all financial aid to Yugoslavia within the tripartite aid program in 1954. That was enough to push Yugoslavia into a new debt crisis, which it

59 Ibid.

60 NARA, RG 459, Entry 1457, Box 3, EPU-1953, Report on 33rd Session of the EPU Managing Board, January 19-24 1953, 29 January 1953, 7.

61 Ibid.

62 NARA, RG 459, Entry 1457, Box 3, EPU-1953, Report on 35rd Session of the EPU Managing Board, March 25-28 1953, 7 April 1953, 6.

63 NARA, RG 459, Entry 1457, Box 3, EPU-1953, Report on 36rd Session of the EPU Managing Board, April 20-25 1953, 30 April 1953, 3. 
tried to solve by acquiring new loans from West Germany and Italy. Thereafter, Yugoslavia reacted to the first signs of crisis by employing bilateral agreements with US help. The US representatives tried to explain to their European allies that the developing Yugoslav economy needed access to Western loans. ${ }^{64}$ In order to bring it closer to the Western institutions and enable it to secure the said loans, Yugoslavia requested OEEC observer status the very same year. This was granted on February 25, $1955 .{ }^{65}$ Yugoslavia's role in the organization developed slowly, since it had to figure out first what its role as an observer actually would be. The first objective both sides had to achieve was adjusting all of Yugoslavia's foreign trade exchange protective measures and getting the exchange system to comply with every EPU stipulation. Yugoslavia eventually succeeded and for that reason, by 1957 it became officially affiliated with the EPU. By 1958, it achieved currency convertibility with the majority of OEEC members and their currencies like other EPU member states. More importantly, the EPU became an important lesson in economic planning and trade with Western European countries for the experts of the Yugoslav federal institutions. ${ }^{66}$

\section{Summary}

The idea of Yugoslavia joining the European clearing and currency convertibility system was not born out of a desire for integration into the Western bloc in general, but out of sheer necessity. In the beginning of the 1950 's, Yugoslavia's foreign trade balances were in deficit, negatively affecting its economic growth and general development. Consequently, the Yugoslav Government lobbied for full membership in the European Payments Union. At the time, the United States was Yugoslavia's largest trading partner, as well as the largest contributor of financial and military aid. In applying its policy of drawing Yugoslavia closer to the Western Bloc after the Cominform crisis of 1948, it sought to influence its West European allies into allowing Yugoslavia to make use of some of the mechanisms implemented by the EPU. However, in the beginning the member states were reluctant to let Yugoslavia align with the Union due to the political reasons surrounding the question of Trieste. Later, the association was prevented by the large trade deficits with most EPU member states. However, in 1953 Yugoslavia was allowed to enter into an affiliation with the

64 Lampe et al., Yugoslav-American Economic Relations, 50.

65 Marković, Obadić, "A Socialist Developing Country", 92.

66 Ibid. 
EPU and use some of its mechanisms. Consequently, Yugoslavia achieved currency convertibility by 1958 along with other West European countries, which was one of the overall motives for the establishment of the EPU as an organization.

\section{Sources and Literature}

- $\quad$ National Archives and Records Administration. Record Group 469 files (RG 469), Records of US foreign assistance agencies, 1948-1961 (RUSFA).

- $\quad$ Adamović, Ljubiša S. Politička i društvenoekonomska kretanja u savremenom svetu. Beograd, 1963.

- $\quad$ August, Byron Gerald. The Economics of International Payments Unions and Clearing Houses. Theory and Measurement. London: Macmillan Press, 1997. DOI: $10.1007 / 978-1-349-25517-7$

- Hogan, Michael J. The Marshall Plan. America, Britain and the Reconstruction of Western Europe, 1947-1952. Cambridge: Cambridge University Press, 1987. DOI: $10.1017 /$ CBO9780511583728

- International Monetary Fund. Balance of Payments Manual. 1993.

- John R. Lampe et al. Yugoslav-American Economic Relations Since World War II. Durham and London: Duke University Press, 1990.

- Kovač, Oskar. Spoljnoekonomska ravnoteža i privredni rast. Problemi i iskustva Jugoslavije. Beograd: Institut ekonomskih nauka, 1973.

- $\quad$ Lees, Lorraine M. Keeping Tito Afloat. The United States, Yugoslavia and the Cold War. Pennsylvania State University, 1997.

- Marković, Andrej, Ivan Obadić. „A Socialist Developing Country in a Western Capitalist Club. Yugoslavia and the OEEC/OECD, 1955-1980". The OECD and the International Political Economy since 1948, eds Matthieu Leimgruber and Matthias Schmelzer, 89-112. London: Palgrave Macmillan, 2017. DOI: 10.1007/978-3-319-60243-1_4

- Milikić, Ratomir. Zaboravljena evropska epizoda: Jugoslavija i Savet Evrope 1949-1958. Beograd: Institut za savremenu istoriju, 2014. (cyrillic)

- Mijatov, Nikola. „Jugoslavija i ujedinjavanje Zapadne Evrope 19501958." Tokovi istorije 2/2016, 177-196. (cyrillic) DOI: 10.31212/tokovi.2016.2.mij.177-196

- Yugoslavia: Political Diaries, 1918-1965, Vol. 4, ed. Robert L. Jarman. London: The Broadway, 1997.

- Foreign Relations of the United States, 1951, Europe: Political and Economic Developments, Vol. IV, Part 2, document 406. Date of access June 2019. https://history.state.gov/historicaldocuments/frus1951v04p2/d406

- Organization for European Economic Co-operation. Date of access June 2019. https://www.oecd.org/general/organisationforeuropeaneconomicco-operation.htm 


\title{
Резиме
}

\author{
Корнелија Ајлец
}

\section{Европска платна унија и преговори о приступању Југославије}

\begin{abstract}
Апстракт: Кроз призму оригиналних извора који се чувају у Националном архиву САД-а и секундарне литературе, чланак се бави америчким аспектом преговора са ФНР Југославијом за приступање Европској платној унији (ЕПУ), који су трајали између 1950. и 1958. године, са главним циљем уклањања препрека у трговини Западне Европе. Југославија никад није постала пуноправна чланица, али јесте постала повезана са њом непосредно пре него што је Унија укинута, кад је Југославија постигла конвертибилност за спољнотрговински робни баланс.
\end{abstract}

Кључне речи: Југославија, Организација за економску сарадњу и развој, ОЕЕЦ, економска помоћ, Европска платна унија

Идеја прикључења Југославије европском систему клиринга и конвертибилности валута није настала из жеље за интеграцијом у Западни блок уопште, већ из чисте потребе. Почетком 50-их спољнотрговински биланси Југославије били су у дефициту, што је негативно утицало на њен економски раст и општи развој. Сходно томе, југословенска влада је лобирала за пуноправно чланство у Европској платној унији. У то време Сједињене Државе су биле највећи трговински партнер Југославије и давале су највећу финансијску и војну помоћ. Примењујући своју политику приближавања Југославије Западном блоку након кризе Коминформа 1948, настојале су да утичу на своје западноевропске савезнике да Југославији омогуће коришћење неких механизама које спроводи ЕПУ. У почетку су државе чланице оклевале да се Југославија приближи Унији због политичких разлога око Трста. Касније су прикључивање спречили велики трговински дефицити са већином земаља чланица ЕПУ. Међутим, 1953. Југославији је дозвољено да ступи у чланство ЕПУ и користи неке од његових механизама. Дакле, до 1958. године Југославија је постигла конвертибилност валуте заједно са осталим западноевропским земљама, што је био један од мотива за успостављање ЕПУ као организације. 